\title{
La música... entre el jardín y el hogar
}

\author{
María Laura Orlando(1)
}

Palabras clave. arte $\cdot$ lenguaje musical · exploración sonora $\cdot$ alumnos/familia

Resumen. El arte es un derecho de todos, incluso desde edades muy tempranas. Por ello, como docentes de niños y niñas pequeños, nos encontramos comprometidos en este proceso, que requiere nutrirnos de «arte» en todas sus manifestaciones, de modo de poder brindar a nuestros alumnos/as experiencias ricas para ser vividas en torno al hecho artístico. El trabajo que aquí se presenta es una propuesta áulica destinada a una sala del primer ciclo del Nivel Inicial, específicamente sala de un año, donde se ofrecen experiencias en torno al lenguaje musical. A través de ella se busca acercar a los niños y niñas al disfrute de la escucha musical, a la exploración sonora de diferentes objetos, del movimiento como respuesta a estímulos sonoros, así como abrir las puertas del arte a las familias, haciéndolas partícipes de las propuestas de la sala.
Keywords. art · musical language . sound exploration $\cdot$ students/family

Abstract. Art is everyone's right, even at a very young age. That is why, as educators of growing children, we find ourselves committed to a teaching process, which requires a constant nourishment of Art in all its forms expressions so that we can provide valuable artistic experiences our students.

This paper introduces a one-year-olds' classroom experience, focused on teaching musical language. It aim is to a bring toddlers closer to developing a taste for music, exploring various sounds by using several objects, analyzing movement as a response to sound stimulation, a and taking art outside the classroom to the students families, inviting them to be part of the classroom plans.

(1) Jardín «La Ronda»,

Universidad Nacional del Litoral.

lauraorlando@hotmail.com 